\title{
Sexual Differentiation of the Brain Requires Perinatal Kisspeptin-GnRH Neuron Signaling
}

\author{
Jenny Clarkson, ${ }^{1}$ Ellen R. Busby, ${ }^{2}$ Milen Kirilov, ${ }^{3}$ Günther Schütz, ${ }^{3}$ Nancy M. Sherwood, ${ }^{2}$ and Allan E. Herbison ${ }^{1}$ \\ ${ }^{1}$ Centre for Neuroendocrinology and Department of Physiology, School of Medical Sciences, University of Otago, Dunedin 9054, New Zealand, ${ }^{2}$ Department \\ of Biology, University of Victoria, Victoria, British Columbia, V8P 5C2 Canada, and ${ }^{3}$ Molecular Biology of the Cell, German Cancer Research Centre, 69120 \\ Heidelberg, Germany
}

\begin{abstract}
Sex differences in brain function underlie robust differences between males and females in both normal and disease states. Although alternative mechanisms exist, sexual differentiation of the male mammalian brain is initiated predominantly by testosterone secreted by the testes during the perinatal period. Despite considerable advances in understanding how testosterone and its metabolite estradiol sexually differentiate the brain, little is known about the mechanism that generates the male-specific perinatal testosterone surge. In mice, we show that a male-specific activation of GnRH neurons occurs $0-2 \mathrm{~h}$ following birth and that this correlates with the male-specific surge of testosterone occurring up to $5 \mathrm{~h}$ after birth. The necessity of $\mathrm{GnRH}$ signaling for the sexually differentiating effects of the perinatal testosterone surge was demonstrated by the persistence of female-like brain characteristics in adult male, GnRH receptor knock-out mice. Kisspeptin neurons have recently been identified to be potent, direct activators of GnRH neurons. We demonstrate that a population of kisspeptin neurons appears in the preoptic area of only the male between E19 and P1. The importance of kisspeptin inputs to GnRH neurons for the process of sexual differentiation was demonstrated by the lack of a normal neonatal testosterone surge, and disordered brain sexual differentiation of male mice in which the kisspeptin receptor was deleted selectively from GnRH neurons. These observations demonstrate the necessity of perinatal GnRH signaling for driving brain sexual differentiation and indicate that kisspeptin inputs to GnRH neurons are essential for this process to occur.
\end{abstract}

Key words: GnRH; GPR54; kisspeptin; sexual differentiation; testosterone

\section{Introduction}

Sexually differentiated brain circuits drive sexually dimorphic behavior and function in many species including humans ( $\mathrm{Si}$ merly, 2002; Luders and Toga, 2010; Kimura, 2011). Although genes expressed off the sex chromosomes play a role (Arnold and Chen, 2009), gonadal steroid hormones are primarily responsible for sexually differentiating the brain acting through perinatal organizational mechanisms (Simerly, 2002; Arnold and Chen, 2009; McCarthy et al., 2012). The organizational effects of the perinatal testosterone surge irreversibly establish a multitude of sexual dimorphisms within the CNS (Arnold, 2009; Lenz et al., 2012; McCarthy et al., 2012). Over recent years considerable effort has focused upon understanding the molecular and cellular mechanisms through which testosterone, and its metabolite estradiol, organize the sexual differentiation of brain structure and

Received July 24, 2014; revised Sept. 29, 2014; accepted 0ct. 2, 2014.

Author contributions: J.C. and A.E.H. designed research; J.C. and E.R.B. performed research;M.K., G.S., and N.M.S. contributed unpublished reagents/analytic tools; J.C. analyzed data; J.C. and A.E.H. wrote the paper.

This work was supported by a Ministry of Science and Innovation New Zealand Science and Technology Postdoctoral Fellowship (Contract U00X0906 to J.C.) and the NZ Health Research Council. We thank Dr. A. Caraty for contributing valuable reagents and Shazia Shamas for technical assistance.

The authors declare no competing financial interests.

Correspondence should be addressed to Allan E. Herbison, Centre for Neuroendocrinology, Department of Physiology, University of Otago, Dunedin 9054, New Zealand. E-mail: allan.herbison@otago.ac.nz.

DOI:10.1523/JNEUROSCI.3061-14.2014

Copyright $\odot 2014$ the authors $\quad 0270-6474 / 14 / 3415297-09 \$ 15.00 / 0$ function (Bakker and Brock, 2010; Forger and de Vries, 2010; McCarthy and Arnold, 2011).

The mechanism underpinning the generation of the perinatal testosterone surge in males is not well understood. One possibility is that male-specific activation of gonadotropinreleasing hormone $(\mathrm{GnRH})$ neurons in the perinatal period elevates luteinizing hormone (LH) secretion that, in turn, drives the perinatal testosterone surge. In support of this hypothesis, $\mathrm{GnRH}$ is able to activate pituitary gonadotrophs from late gestation onward (Wen et al., 2010), and testosterone levels are known to become dependent upon GnRH and LH in the days following birth in male rodents (O'Shaughnessy et al., 1998). Further, male rats as well as humans exhibit elevated LH levels concurrent with the perinatal testosterone surge (Corbier et al., 1978; de Zegher et al., 1992). However, other investigators have found contradictory results (Pang et al., 1979; McGivern et al., 1995) and studies examining the $h p g$ mutant mouse, deficient in GnRH, have also reported conflicting observations in relation to brain sexual differentiation (Livne et al., 1992; Gill et al., 2010; Poling and Kauffman, 2012).

Kisspeptin signaling through Gpr54 is now acknowledged to be one of the most potent activators of $\mathrm{GnRH}$ neurons with key roles in puberty onset and adult reproductive functioning (Roa et al., 2011; Kirilov et al., 2013). There is also growing evidence that kisspeptin may regulate the activity of GnRH neurons in the perinatal period. Embryonic GnRH neurons express Gpr54 and re- 
spond to kisspeptin (Constantin et al., 2009; Fiorini and Jasoni, 2010; Knoll et al., 2013; Kumar et al., 2014), a male-biased sex difference in Gpr54 expression by GnRH neurons is observed at birth (Herbison et al., 2010), and a recent study has shown that arcuate nucleus (ARN) kisspeptin neurons begin to form synapses with GnRH neurons from mid-gestation onward (Kumar et al., 2014).

In the present series of investigations we have used genetically modified mouse models to examine the hypothesis that kisspeptin inputs to GnRH neurons are required for the perinatal activation of testosterone secretion in males that leads to sexual differentiation of the brain. In the first series of studies we readdress the role of GnRH neuron signaling in generating sexual dimorphisms in the brain and in the second series we examine the necessity of kisspeptin inputs to GnRH neurons in this process.

\section{Materials and Methods}

Animals. All experiments were approved by the University of Otago Animal Welfare and Ethics Committee or the Animal Care Committee of University of Victoria. Mice were housed under a $12 \mathrm{~h}$ light/dark lighting schedule (lights on at 6:00 A.M.) with ad libitum access to food and water. Experiments were undertaken on wild-type and two genetically modified C57BL/6J mouse lines: GnRH receptor-null mice (GnRHR-KO; Wu et al., 2010) and mice with GnRH neuron-selective deletion of Gpr54 (GnRH-Gpr54KO; Kirilov et al., 2013). The sex of embryonic and early postnatal mice was confirmed with PCR as detailed previously (Simonian and Herbison, 2001).

Collection of samples from embryonic and early postnatal mice. Timedpregnant female wild-type mice were killed by cervical dislocation on E17 or E19, the uteri were removed, and the embryos dissected from the uteri. For the collection of blood or brain samples from early postnatal mice, timed-pregnant mice were checked every $2 \mathrm{~h}$ from E18 until the birth of the litter (designated as P0). Care was taken to disturb dams as little as possible during the checking process, and during the dark phase mice were checked under red light illumination. Brains of $\mathrm{P} 0$ male and female mice were collected 2-3 h after birth for immunohistochemical (IHC) studies of GnRH neurons ( $n=4 / \mathrm{sex})$. Brains were collected from E17 and $\mathrm{E} 19$ and P0, P1, and P5 mouse pups of both sexes for kisspeptin IHC studies $(n=2-12 /$ sex/age $)$.

Blood was collected from P0 pups in $1 \mathrm{~h}$ time intervals over the first $4 \mathrm{~h}$ following delivery of the litter, and also from P2 and P7 mice following decapitation. To provide sufficient volume for analysis, it was necessary to pool plasma from two P0 pups ( $n=3-18$ pools/time interval/sex). P2 and $\mathrm{P} 7$ pups provided sufficient plasma volume for individual analysis. Blood was collected from GnRH-Gpr54KO mice and littermates 1-2 h following delivery of the litter ( $n=8-18$ per group). Plasma was collected after centrifugation of the blood samples at $4 \mathrm{G}$ for $4 \mathrm{~min}$ and then stored at $-20^{\circ} \mathrm{C}$ until assayed. The testosterone levels were determined using an ELISA for total testosterone (DEV9911; Demeditec Diagnostics). The sensitivity was $0.05 \mathrm{ng} / \mathrm{ml}$ and the intra-assay coefficient of variations were $1.30 \%$ (Experiment 1 ) and $5.37 \%$ (Experiment 6).

Timed-pregnant dams were given a subcutaneous injection of $100 \mu \mathrm{l}$ of sesame oil or sesame oil containing $1 \mathrm{mg}$ of either testosterone propionate or dihydrotestosterone (DHT) on E18. Dams were allowed to deliver naturally and the brains of the pups were collected on P0 $(n=$ $4-5 /$ sex/treatment).

Adult gonadectomy and testosterone replacement. To examine perinatal organizational actions of sex steroids on brain sexual differentiation, wild-type and mutant mice were gonadectomized (GDX) in the peripubertal period and testosterone immediately replaced to normalize the activational effects of sex steroids among the different genotypes. Although there is increasing evidence that gonadal steroids can have an impact on female brain sexual differentiation between the perinatal and postpubertal period (Campbell and Herbison, 2014), the present approach is very likely to isolate the effects of perinatal organizational actions of gonadal steroids in males. Mice (P41-P45) were GDX under isoflurane anesthesia and given a subcutaneous testosterone implant.
Two weeks later mice were re-anesthetized and perfused. Testosterone implants were constructed from SILASTIC brand silicon tubing (i.d. 1.47 $\mathrm{mm}$; o.d. $1.95 \mathrm{~mm}$ ) cut into $1 \mathrm{~cm}$ long pieces, filled with micronized testosterone, and sealed at both ends with SILASTIC brand adhesive.

Immunohistochemistry. Brains of embryonic and early postnatal mice were dissected and emersion fixed in $4 \%$ paraformaldehyde in $0.1 \mathrm{M}$ phosphate buffer, $\mathrm{pH}$ 7.6, for $4 \mathrm{~h}$. The brains were then transferred to a TBS ( $0.5 \mathrm{~m}$ Tris, $0.15 \mathrm{~m}$ sodium chloride, $\mathrm{pH}$ 7.6) solution overnight. A single set of $50-\mu \mathrm{m}$-thick coronal brain sections was cut from each animal on a vibrating microtome (Leica VT1200S) from the medial septum through to the end of the ARN. Sections were transferred into netwells (Corning) to prevent damage from manual tissue transfer during freefloating IHC procedures. For the collection of brains from mice aged P5 and adult, animals were anesthetized with an intraperitoneal injection of sodium pentobarbital $(3 \mathrm{mg} / 100 \mu \mathrm{l})$ and perfused directly through the left ventricle of the heart with $5 \mathrm{ml}$ (P5 mice) or $15 \mathrm{ml}$ (adult mice) of 4\% paraformaldehyde in $0.1 \mathrm{~m}$ phosphate buffer, $\mathrm{pH}$ 7.6. The brains were removed from the skull and post fixed in the same fixative for $60 \mathrm{~min}$ at $4^{\circ} \mathrm{C}$, then transferred to a $30 \%$ sucrose-TBS solution overnight. Brains from adult mice were frozen on the stage of a sliding microtome, and two sets of coronal sections ( $30 \mu \mathrm{m}$ thick) were cut from the medial septum through to the end of the ARN. One of the two sets of sections from each mouse was used for IHC.

Free-floating single- or double-label IHC was undertaken as previously reported (Clarkson et al., 2008, 2009b). Briefly, brain sections were incubated for $48 \mathrm{~h}$ at $4^{\circ} \mathrm{C}$ in well characterized polyclonal primary antisera directed against either cFos (rabbit, 1:8000; SC52; Santa Cruz Biotechnology; Li et al., 1999), vasopressin (guinea pig anti-( $\left.\operatorname{Arg}^{8}\right)$ vasopressin antiserum, 1:30,000; Peninsula Laboratories; Alves et al., 1998), TH (rabbit, 1:5000; Merck Millipore; Bu and Lephart, 2007), or kisspeptin (rabbit, 1:10,000; \#566, A. Caraty, Institut National de la Recherche Agronomique; Clarkson et al., 2009b). Sections were then incubated in biotinylated anti-rabbit or anti-guinea pig immunoglobulins (1:400; Vector Laboratories) followed by Vector Elite avidin-peroxidase (1:400; Vector Laboratories) and nickel-enhanced DAB that resulted in a black precipitate within either the nucleus ( $\mathrm{cFos}$ ) or the cytoplasm (vasopressin, TH, or kisspeptin) of the labeled cell. For the second immunolabeling, sections were incubated in 3\% hydrogen peroxide to quench any remaining peroxidase activity and then washed and incubated in a GnRH antiserum (polyclonal rabbit, 1:20,000; LR5, R. Benoit, Montreal, Canada; Hoffman et al., 1990) followed by peroxidase-conjugated antirabbit immunoglobulins (1:400; Vector Laboratories) and DAB without nickel to generate a brown precipitate within the cytoplasm. Controls consisted of experiments in which each primary antibody was omitted from the IHC procedures.

IHC analysis. For the single-label TH and kisspeptin IHC, the number of TH- or kisspeptin-immunoreactive cell bodies located within the anteroventral periventricular nucleus (AVPV), rostral preoptic periventricular nucleus, and caudal pre-optic periventricular nucleus were counted. Collectively, these brain regions are termed the rostral periventricular area of the third ventricle (RP3V; Herbison, 2008; Clarkson et al., $2009 \mathrm{~b}$ ). For the embryonic and early postnatal brains, every section of the $\mathrm{RP} 3 \mathrm{~V}$ was analyzed in each mouse (three to five sections per mouse), and the number of kisspeptin-positive cells on each side of the third ventricle counted and presented as the estimated total number of cells per RP3V per mouse. For the adult mice, two brain sections at each level of the RP3V were analyzed in each mouse, and the number of TH or kisspeptinpositive cells counted. Cell counts for each area were determined and then combined to produce the mean number of TH or kisspeptin neurons per section for the RP3V of each mouse. The mean numbers of TH or kisspeptin cells per section in the RP3V of each mouse were then grouped to provide mean \pm SEM values for the experimental groups. For all experiments, the analyzer was blind to the treatment of the animals.

For the single-label vasopressin IHC, the density of vasopressin fiber staining in the lateral septum (LS) was determined. Images of the left and right lateral septi were captured at $10 \times$ magnification with a SPOT RT (SPOT Imaging Solutions) digital camera and SPOT software under bright-field illumination. The light intensity and camera settings were kept constant across the sections to standardize the measurements. For 
each mouse, the density of vasopressin-immunoreactive fibers in the LS was examined in the section that corresponded to Figures $29-30$ in the Paxinos and Franklin (2001) brain atlas. Fiber density in the LS was analyzed using the NIH ImageJ software. First each image was converted to grayscale and then an identical threshold was applied to each image to obtain a binary image. An identical $\left(75 \mu \mathrm{m}^{2}\right)$ oval-shaped region of interest (ROI) was applied immediately adjacent to the lateral ventricle on each binary image, and the mean gray value (MGV) within the ROI was measured as an index of vasopressin fiber density. The MGV for the left and right LS were averaged to give a single value for each mouse. The MGV for each mouse was then grouped to provide mean \pm SEM values for the experimental groups.

Analysis of the double-labeled tissue was undertaken by counting the number of single-labeled (brown cytoplasm only) and dual-labeled (brown cytoplasm and black nucleus) GnRH neurons in the preoptic area (POA). At least two brain sections representing the POA (Paxinos and Franklin, 2001, their plates 26-28) were counted per mouse. The percentage of GnRH neurons coexpressing cFos in each area was determined and then grouped to produce a mean percentage of coexpression per section in each mouse. The mean data from each mouse was then grouped to provide mean \pm SEM values for the experiment.

Statistical analysis. Statistical tests are described in the Results section for each experiment. The $t$ tests and one-way ANOVA analyses were conducted using Prism 5.0b (GraphPad Software), and two-way ANOVA analyses were performed using SigmaPlot 12.0 (Systat Software).

\section{Results}

\section{Experiment 1: testosterone levels are elevated at birth in} male mice

We first established the profile of neonatal testosterone secretion in wild-type male and female mice over the first hours of life and on $\mathrm{P} 2$ and $\mathrm{P} 7$. There was a significant effect of sex $\left(F_{(1,106)}=\right.$ $30.99 ; p=0.001)$ and age $\left(F_{(7,106)}=3.03 ; p=0.014\right)$ on the level of plasma testosterone (two-way ANOVA for sex and age with post hoc Student-Newman-Keuls pairwise comparisons). Testosterone concentrations in male pups were elevated over the first $4 \mathrm{~h}$ of life with peak levels observed 1-2 h after birth (Fig. 1A), which declined to low levels on P2 and P7. Female pups exhibited unvarying low levels of testosterone throughout the neonatal period (Fig. 1A). There was a significant sex difference in the level of plasma testosterone at $0-1 \mathrm{~h}(p<0.05), 1-2 \mathrm{~h}(p<0.001), 2-3$ $\mathrm{h}(p<0.001)$, and $3-4 \mathrm{~h}(p<0.05)$ post birth.

\section{Experiment 2: male-specific activation of $\mathrm{GnRH}$ neurons at birth}

The role of $\mathrm{GnRH}$ neurons in generating the neonatal testosterone surge remains unclear in any species. We used the fact that GnRH neurons only express cFos during periods of intense electrical activity (Hoffman et al., 1993) to investigate whether male GnRH neurons are activated at the time of birth. As the testosterone surge peaks at $1-2 \mathrm{~h}$ (Fig. $1 A$ ), we examined for expression of cFos protein in GnRH neurons $1 \mathrm{~h}$ later in the $2-3 \mathrm{~h}$ period after birth. GnRH neurons were distributed in the typical "inverted Y" distribution within the preoptic area and cFos-positive cells were identified throughout the brain of both sexes. Dual-label IHC revealed that $13.1 \pm 2.0 \%$ of $\mathrm{GnRH}$ neurons were positive for cFos in male pups compared with $1.8 \pm 0.8 \%$ in females $(p<$ 0.05 , Mann-Whitney $U$ test; $n=4$ each sex; Fig. $1 B-E)$. The number of GnRH neurons counted did not exhibit a sex difference $(34.5 \pm 3.0$ male, $32.6 \pm 0.5$ female cells per brain section; $p>0.05)$
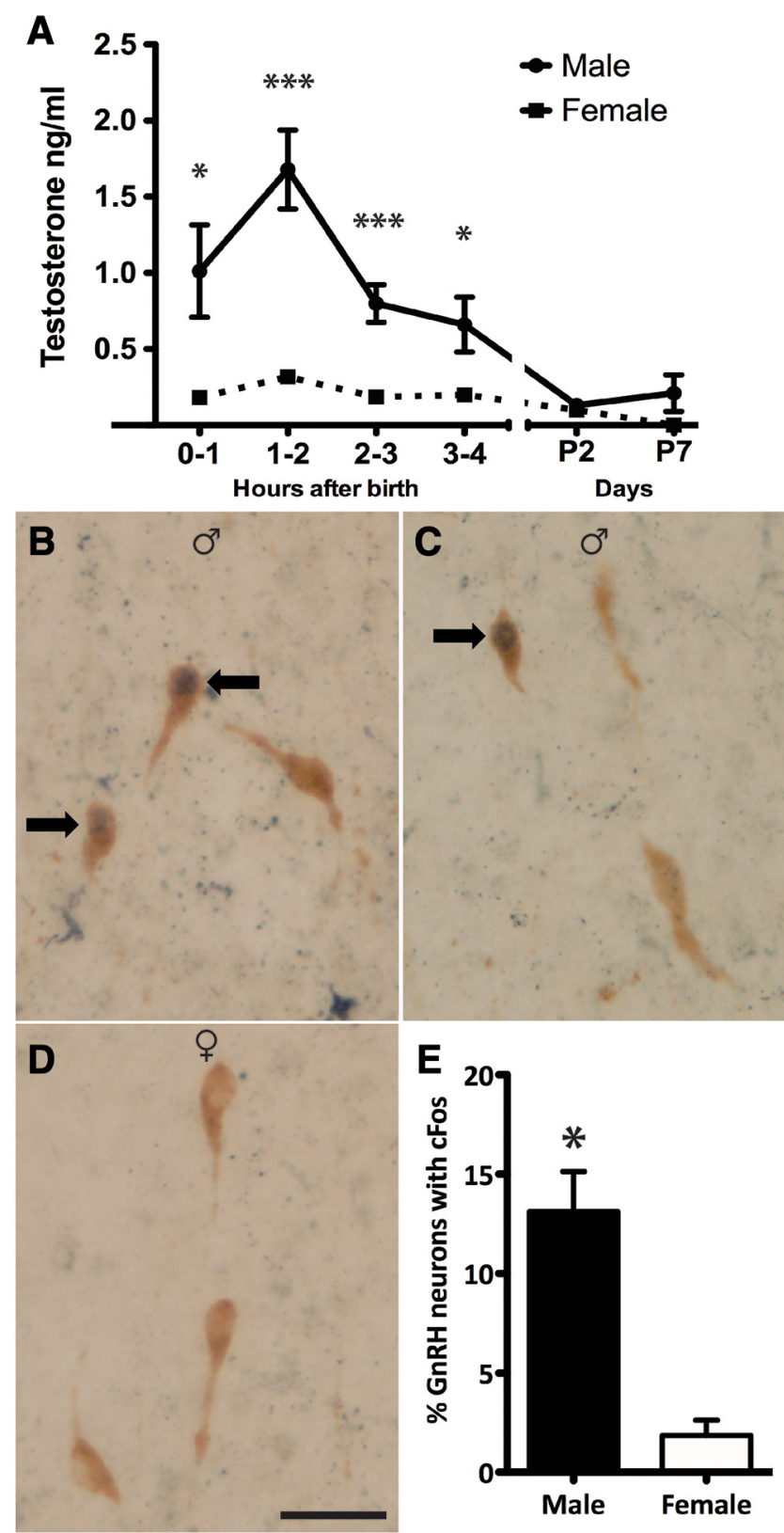

Figure 1. The sexually dimorphic testosterone surge is accompanied by sexually dimorphic activation of $\mathrm{GnRH}$ neurons in the rostral POA (rPOA). $\boldsymbol{A}$, Plasma testosterone levels in male and female mice killed at hourly intervals after birth on P0 and on P2 and P7 ( $n=3-19$ pools of 2 mice/time point/sex). Groups were compared with a two-way ANOVA for sex and time post birth; with post hoc Student-Newman-Keuls pairwise comparisons; sex $p<0.001$, time post birth $p<0.014 .{ }^{*} p<0.05,{ }^{* * *} p<0.001$. B, C, Dual-label immunocytochemistry showing rPOA GnRH neurons (brown cytoplasm) and CFos-immunoreactive nuclei (black) in male and female $(\boldsymbol{D})$ mouse pups 2-3 h after birth. Arrows indicate dual-labeled $\mathrm{GnRH}$ neurons ( $n=$ 4/sex). Scale bar, $20 \mu \mathrm{m}$. $\boldsymbol{E}$, Quantification of the percentage of $\mathrm{GnRH}$ neurons expressing cFos in male and female mouse pups 2-3 h after birth. Groups were compared using a MannWhitney $U$ test.

\section{Experiment 3: deletion of the $\mathrm{GnRH}$ receptor results in} defective sexual differentiation of the brain

Male-specific GnRH neuron activation and elevated testosterone levels in the first few hours after birth suggested that GnRH neurons may initiate the testosterone surge and thereby sexual differentiation of the brain. To test this hypothesis, we examined two well established neurochemical sex differences in the brains of GnRHR-KO and control mice that were GDX in the peripu- 
bertal period and treated with testosterone for 2 weeks $(\mathrm{GDX}+\mathrm{T})$. This effectively clamps activational actions so that perinatal organizational effects of testosterone can be examined. The two markers of sexual differentiation were the male-dominant vasopressin fiber innervation of the LS (De Vries and Panzica, 2006) and the female-dominant TH neuron population of the RP3V (Simerly, 1989, 1997). Both sex differences are generated primarily from classical organizational and activational actions of testosterone.

Vasopressin

First, we confirmed (De Vries and Panzica, 2006) the robust $\sim 6$-fold maledominant sex difference in LS vasopressin fiber innervation in intact wild-type mice ( $p=0.008$, one-way ANOVA with post hoc Student-Newman-Keuls tests; $p<0.01$; Fig. 2A,B,E). We then examined LS vasopressin fiber density in male GnRHR-KO and control mice. As expected, vasopressin levels were not different between wildtype intact and wild-type GDX $+\mathrm{T}$ males ( $p>0.05$; Fig. 2A,C,E). However, male GDX + T GnRHR-KO mice exhibited a profound 75\% reduction in LS vasopressin fiber density $(p<0.05$; Fig. $2 C-E)$ compared with GDX + T controls and exhibited a vasopressin density not different to that of wild-type females $(p>0.05$; Fig. $2 B, D, E)$. This indicates that $\mathrm{GnRH}$ receptor signaling in the perinatal period is essential for male-dominant sex-differences in the brain.

\section{Tyrosine hydroxylase}

As documented previously (Simerly, 1989, 1997), an $\sim 1.5$-fold, female-dominant sex difference was detected in the number of TH cell bodies located in the RP3V of intact wild-type mice ( $p=$ 0.003 , one-way ANOVA with post hoc Student-Newman-Keuls tests; Fig. $2 F, G, J)$. As expected, TH cell counts were not different between wild-type intact and wild-type GDX + T males $(~ p>0.05$; Fig. $2 F, H, J)$. However, GDX+T GnRHR-KO mice exhibited TH cell numbers intermediate between intact males and females with numbers of TH neurons trending toward being female like compared with the wild-type GDX $+\mathrm{T}$ male mice $(p=0.11$, Fig. $2 H-J)$. This indicates that $\mathrm{GnRH}$ receptor signaling in the perinatal period may also contribute to female-dominant sex differences.

\section{Experiment 4: kisspeptin neurons exist transiently in the $\mathrm{RP} 3 \mathrm{~V}$ during the perinatal period in male mice}

We examined whether kisspeptin neurons may be involved in activating GnRH neurons in males to generate the perinatal testosterone surge. Previous studies have suggested that the kisspeptin neurons of the ARN may not provide a sexually dimorphic input to GnRH neurons around the time of birth (Clarkson and Herbison, 2006; Desroziers et al., 2012b; Knoll et al., 2013). Further, the RP3V kisspeptin population is not reported to synthe- size kisspeptin until the second week of birth in mice (Clarkson and Herbison, 2006; Semaan et al., 2010; Desroziers et al., 2012a). To re-evaluate this scenario, we undertook a detailed series of IHC studies examining kisspeptin expression in the hypothalamus from E17 to P5. This study revealed that there is indeed a small population of $\sim 15$ kisspeptin neurons located in the RP3V during the perinatal period and that, interestingly, they only exist in male pups (Fig. $3 A-C$ ). Whereas only a very few kisspeptin neurons were detected at E17, this increased over E19 $(p<0.001$; two-way ANOVA for sex and age with post hoc Student-Newman-Keuls pairwise comparisons), to peak at $\mathrm{P} 0(p<0.001)$, before declining at P1 $(p<0.015)$ to zero on P5 in males $(p=$ $0.008 ; n=2-12 /$ sex at each time point; Fig. $3 C$ ). Kisspeptinimmunoreactive neurons were never detected in the RP3V of females at any developmental time point $(n=2-12$ at each time point; Fig. $3 B)$. There was a significant sex difference at E19 $(p<$ $0.001), \mathrm{P} 0(p<0.001)$, and P1 $(p<0.001)$. Overall there was a significant effect of $\operatorname{sex}\left(F_{(1,50)}=98.940 ; p<0.001\right)$, age $\left(F_{(4,50)}=\right.$ $46.505 ; p<0.001)$, and a significant interaction $\left(F_{(4,50)}=45.413\right.$; $p<0.001)$ on the number of neurons expressing kisspeptin in the $\mathrm{RP} 3 \mathrm{~V}$. As reported by others, immunoreactivity for kisspeptin 


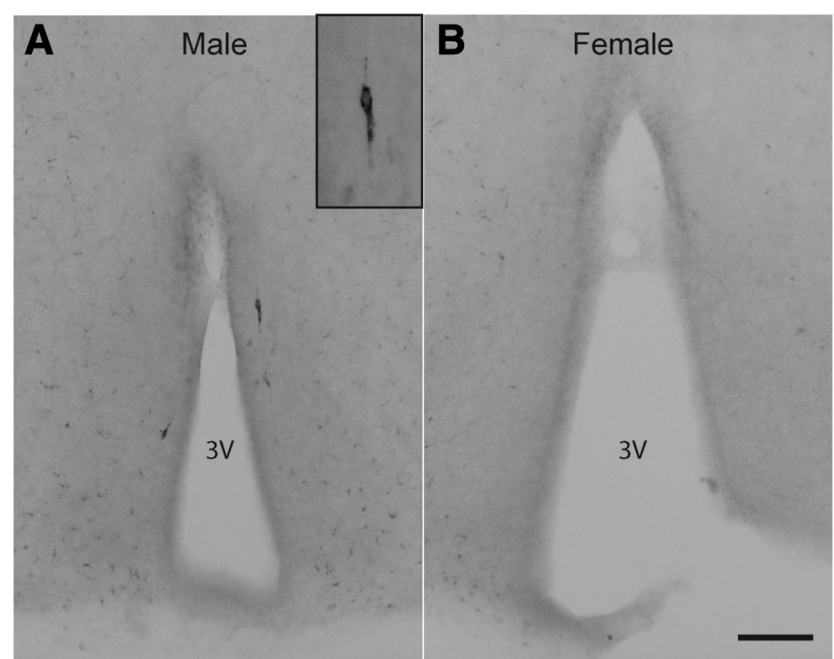

C

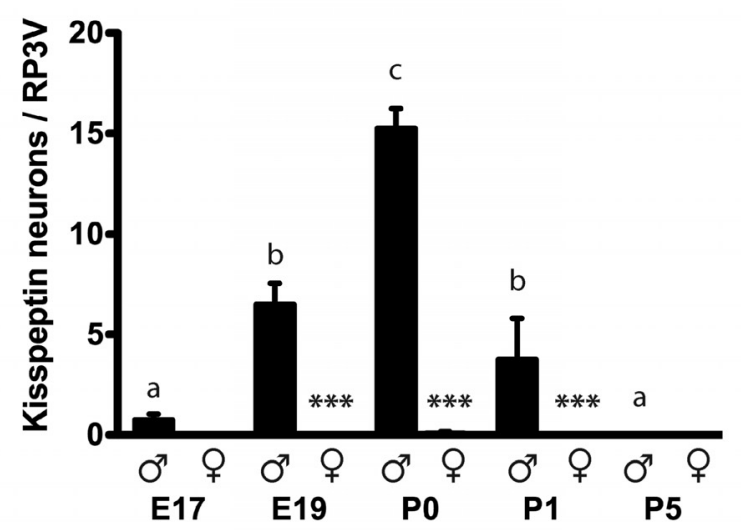

D

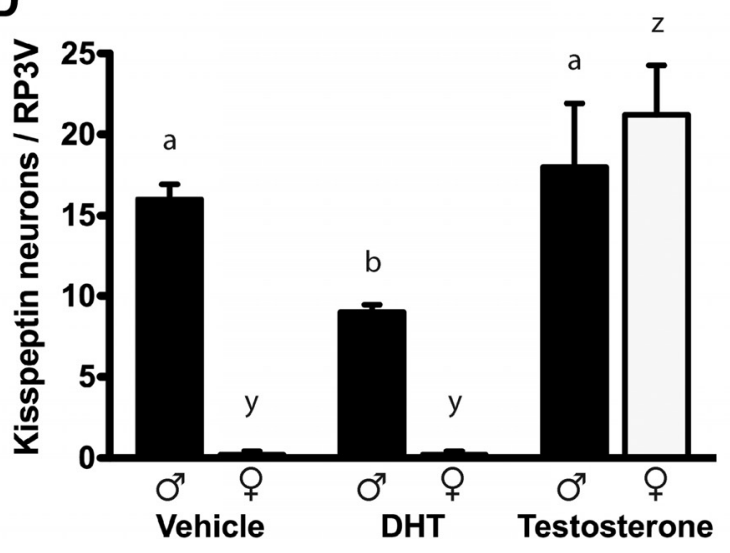

Figure 3. Sexually dimorphic expression of RP3V kisspeptin neurons in perinatal mice is regulated by prenatal testosterone exposure. Kisspeptin-immunoreactive cell bodies were detected in the RP3V of P0 male $(\boldsymbol{A})$ but not female $(\boldsymbol{B})$ mice. $\boldsymbol{C}$, Quantitative analyses (mean \pm SEM) of the number of kisspeptin-immunoreactive neurons in the RP3V in male and female mice from E17 to P5 ( $n=2-12 /$ sex/age). $\boldsymbol{D}$, Quantitative analyses (mean \pm SEM) of the number of kisspeptin-immunoreactive neurons in the RP $3 \mathrm{~V}$ in $\mathrm{PO}$ male and female mouse pups from dams treated with vehicle, or $1 \mathrm{mg}$ of either DHT or testosterone on $\mathrm{E} 18(n=4-5 / \mathrm{sex}$ / treatment). Inset shows a higher power image of a single kisspeptin neuron. Scale bar, $100 \mu \mathrm{m}$. Groups were compared with a two-way ANOVA for sex and age/treatment with post hoc Student-Newman-Keuls pairwise comparisons. C, Sex $(p<0.001)$, age $(p<0.001)$, and interaction $(p<0.001)$; asterisks indicate differences between males and females at the ages indicated ${ }^{* * *} p<0.001$. D, Sex $(p<0.001)$, treatment $(p<0.001)$, and interaction $(p<$ 0.001 ). Bars labeled with different letters are significantly different from each other at either $p<0.05$ or $p<0.001$ (see text). 3V, third ventricle. within the arcuate nucleus did not appear different between males and females at any of the developmental time points examined. This study demonstrates that a small population of RP3V kisspeptin neurons exists at the time $\mathrm{GnRH}$ neurons are activated in the perinatal male.

The above studies identified a male-specific expression of kisspeptin within RP3V neurons that peaked between E19 and P0. We next questioned what may drive this event. Previous studies have indicated that an early gonadotropin-independent rise in plasma testosterone levels occurs during late embryogenesis (E14-E19) in male rats and mice (Pointis et al., 1980; Weisz and Ward, 1980; O'Shaughnessy et al., 1998). In postnatal life, kisspeptin synthesis within the RP3V population is regulated by circulating or aromatized estradiol levels in both sexes (Clarkson et al., 2009a, 2012). We therefore speculated that this early malespecific testosterone secretion might be responsible for the transient activation of kisspeptin biosynthesis in the RP3V around birth. Timed-pregnant female mice were injected with testosterone or the nonaromatizable androgen DHT on E18 and the effects on kisspeptin neuron number determined in male and female pups on P0 ( $n=4-5 /$ sex/treatment). There was a significant effect of $\operatorname{sex}\left(F_{(1,27)}=25.294 ; p<0.001\right)$, treatment $\left(F_{(2,27)}=39.577\right.$; $p<0.001)$, and a significant interaction $\left(F_{(2,27)}=15.452 ; p<0.001\right)$ on the number of kisspeptin neurons in the RP3V of pups from steroid-treated dams (two-way ANOVA for sex and age with post hoc Student-Newman-Keuls pairwise comparisons). The pups from vehicle-treated dams exhibited the normal pattern of kisspeptin expression with $\sim 15$ cells detected in the RP3V of males and none in female (Fig. 3D). Testosterone, but not DHT, induced the appearance of $\sim 20$ kisspeptin neurons within the RP3V of P0 female pups (Fig. 3D; $p<0.001$ ). There was no difference between the number of RP3V kisspeptin neurons in male pups from vehicle- and testosterone-treated dams ( $p=$ 0.433 ), although male pups from the DHT-treated dams only had $\sim 10$ kisspeptin neurons $(p<0.05)$. This study indicates that, following aromatization to estradiol, embryonic testosterone can induce kisspeptin expression in the RP3V at birth.

\section{Experiment 5: GnRH neuron-specific deletion of Gpr54} results in defective sexual differentiation of the brain To examine directly the hypothesis that kisspeptin-Gpr54 signaling at the GnRH neuron is involved in sexual differentiation of the brain, we used a GnRH neuron-specific Gpr54 knock-out mouse line (Kirilov et al., 2013). Again, we reasoned that an essential perinatal role for kisspeptin signaling at the GnRH neuron in brain sexual differentiation would be revealed by peripubertal GDX $+\mathrm{T}$ treatment of control and GnRH-Gpr54KO mice.

\section{Vasopressin}

Wild-type GDX + T male and female control mice exhibited the normal $\sim 6$-fold difference in LS vasopressin density $(p<0.001$, two-way ANOVA with post hoc Student-Newman-Keuls tests; Fig. $4 A, B, E)$. In contrast, adult GDX+T GnRH-Gpr54KO males exhibited an $\sim 80 \%$ reduction in fiber density $(p<0.001)$ making them equivalent to both GDX+T wild-type and GnRHGpr54KO female mice ( $p>0.05$; Fig. $4 C-E)$. There was a significant effect of sex $\left(F_{(1,22)}=36.994, p<0.001\right)$, genotype $\left(F_{(1,22)}=31.656, p<0.001\right)$, and a significant interaction $\left(F_{(1,22)}=\right.$ $33.245, p<0.001)$ on the density of vasopressin fibers in the LS (two-way ANOVA for sex and genotype with post hoc Student-Newman-Keuls pairwise comparisons). 
Tyrosine hydroxylase

Wild-type GDX + T male and female control mice exhibited the normal $\sim 1.5$-fold difference in $\mathrm{TH}$ neuron numbers in the RP3V $(p<0.001$, two-way ANOVA with post hoc Student-Newman-Keuls tests; Fig. $4 F, G, J)$. However, adult GDX $+\mathrm{T}$ GnRH-Gpr54KO mice failed to exhibit a sex difference in TH cell numbers with male mice exhibiting higher numbers of $\mathrm{TH}$ neurons compared with GDX $+\mathrm{T}$ control males $(p=0.017$; Fig. $4 F, H, J)$ and these levels were no longer different compared with female mice $(p>0.05$; Fig. $4 J)$. Overall, there was a significant effect of $\operatorname{sex}\left(F_{(1,22)}=28.640, p<0.001\right)$ and an interaction between sex and genotype $\left(F_{(1,22)}=5.871, p=0.026\right)$. These data demonstrate that Gpr54 signaling at the GnRH neuron is required for establishing normal male- and femaledominant sex differences in the brain.

\section{Experiment 6: GnRH neuron-specific deletion of Gpr54 results in a blunted neonatal testosterone surge}

The results of the above studies indicate that disrupted kisspeptin signaling to $\mathrm{GnRH}$ neurons in male mice results in disordered brain sexual differentiation. To test directly whether this results from abnormal neonatal testosterone secretion we collected blood from male and female wild-type control and GnRH-Gpr54KO pups at the time of peak neonatal testosterone secretion $1-2 \mathrm{~h}$ following birth ( $n=8-18 /$ sex/genotype). Wild-type littermates displayed the expected sex difference in plasma testosterone concentrations ( $p<0.001$; Fig. 5 ; two-way ANOVA for sex and genotype with post hoc Student-Newman-Keuls pairwise comparisons). In contrast, male GnRH-Gpr54KO pups exhibited significantly ( $p=0.005$; Fig. 5 ) reduced testosterone levels compared with wild-type male pups that were no longer different to that of female pups $(p=0.14)$. Overall, a significant effect of sex on the level of plasma testosterone $\left(F_{(1,49)}\right.$ $=17.390, p<0.001)$, and a near-significant effect of genotype $\left(F_{(1,49)}=3.837, p=0.056\right)$ were detected. These data demonstrate that Gpr54 signaling at the GnRH neuron is essential for the normal neonatal testosterone surge in males.

\section{Discussion}

These investigations support the concept that kisspeptin neurons are involved in activating GnRH neurons in males during the perinatal period to generate the neonatal testosterone surge responsible for organizing brain sexual dimorphisms. We provide a detailed profile of testosterone secretion over the neonatal period in mice and show that a male-specific activation of GnRH neurons occurs at this time. Further, we present evidence that $\mathrm{GnRH}$ receptor signaling is essential for organizing the robust, maledominant sex difference in vasopressin fiber innervation of the LS, and likely contributes to the proper sexual differentiation of the preoptic area dopamine neurons. We also demonstrate a key role for kisspeptin signaling at the GnRH neurons in this process. Studies with GnRH-Gpr54KO mice showed that kisspeptin inputs to $\mathrm{GnRH}$ neurons were required for the neonatal testosterone surge as well as the organizational sex differences in the male-dominant vasopressin innervation of the LS and female-dominant number of preoptic area dopamine neurons. Although the source of these kisspeptin inputs to GnRH neurons remains unknown, we reveal here a previously unidentified population of male-specific RP3V cells that express kisspeptin transiently across the perinatal period.

Prior investigations exploring the role of GnRH neurons in the generation of the neonatal testosterone surge and brain sexual differentiation have not provided a consensus view. In support of a role for $\mathrm{GnRH}$ neurons, male rats treated in the first few days of life with a gonadotropin antiserum show incomplete sexual differentiation of sexual behavior (Goldman and Mahesh, 1970; Goldman et al., 1972). Further, studies in rats and humans show that gonadotropins are elevated at the time of the neonatal testosterone surge (Corbier et al., 1978; de Zegher et al., 1992). However, other investigators have reported that the testosterone 


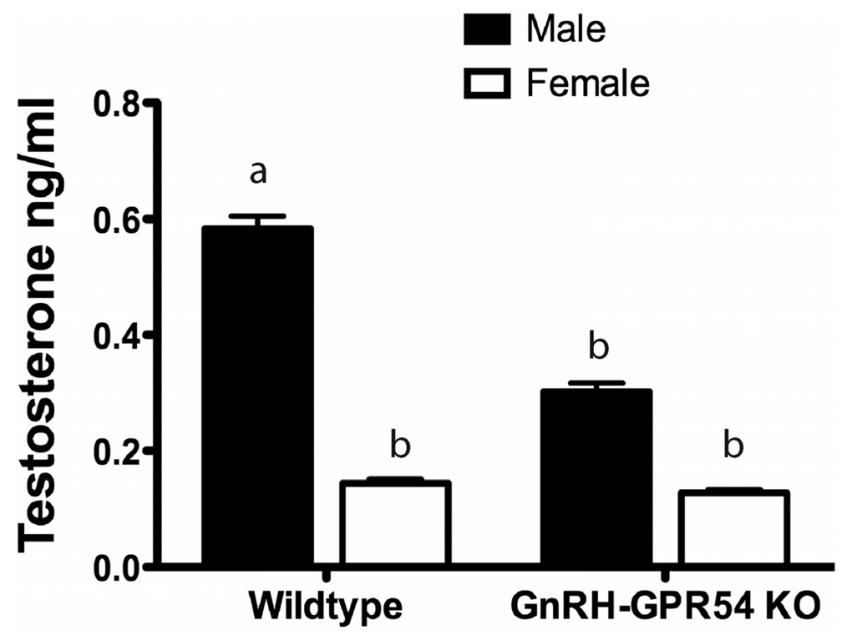

Figure 5. Disrupting kisspeptin-Gpr54 signaling at the GnRH neuron blunts the neonatal testosterone surge. Quantitative analysis (mean \pm SEM) of the level of plasma testosterone $1-2 \mathrm{~h}$ after birth in male and female wild-type and GnRH-Gpr54KO mice ( $n=8-18 / \mathrm{sex}$ / genotype). Groups were compared using a two-way ANOVA with post hoc Student-NewmanKeuls pairwise comparisons; $\operatorname{sex} p<0.001$, genotype $p=0.05$. Bars labeled with different letters are significantly different from each other at either $p<0.01$ or $p<0.001$ (see text).

surge is independent of $\mathrm{GnRH}$ receptor activation and gonadotropin secretion in rodents (Pang et al., 1979; Baum et al., 1988; McGivern et al., 1995).

We describe here the profile of testosterone secretion across the first few hours following birth and show that males exhibit peak levels of testosterone $\sim 6$-fold higher than those of females in the 1-2 h interval after birth, similar to a previous report in mice (Corbier et al., 1992). Taking insight from this profile we then examined cFos protein expression in GnRH neurons $1 \mathrm{~h}$ following peak testosterone levels and found that $13 \%$ of $\mathrm{GnRH}$ neurons were positive for cFos in males compared with $2 \%$ in females. We note that a recent paper failed to detect a sex difference in cFos mRNA expression in GnRH neurons in the neonatal period (Poling and Kauffman, 2012). This likely reflects their use of the wide $0-4 \mathrm{~h}$ post birth sampling period, examination of cFos mRNA that is transient compared with protein, and the relative insensitivity of dual in situ hybridization compared with dual DAB IHC. To our knowledge we provide here the first evidence for a male-specific activation of GnRH neurons in the neonatal period and offer important support for the concept that $\mathrm{GnRH}$ neurons are involved in generating the neonatal testosterone surge. This also suggests that, just as in monkeys (Plant, 1985), there is an initial activation of the hypothalamo-pituitarygonadal axis after birth with a subsequent hiatus until puberty onset in male rodents.

In addition to observing a male-specific activation of $\mathrm{GnRH}$ neurons at the time of the neonatal testosterone surge, we also found that brain sexual differentiation is disrupted in mice lacking GnRH receptor signaling. The male-dominant sexual dimorphism in LS vasopressin fiber innervation was completely transformed into a female-like pattern of expression, while the female-dominant sex difference in preoptic TH neuron numbers trended toward a female-like pattern in male mice lacking $\mathrm{GnRH}$ receptors. These results are congruent with previous work demonstrating abnormalities in kisspeptin sexual differentiation in male $h p g$ mice where the number of RP3V kisspeptin neurons is increased in male $h p g$ mice compared with their wild-type littermates (Gill et al., 2010). We did not assess neonatal testosterone levels in the GnRHR-KO mice in the present experiments. Nev- ertheless, the combination of our plasma testosterone and $\mathrm{GnRH}$-cFos studies in wild-type mice coupled with the findings in GnRHR-KO mice suggest an important role for GnRH neurons in the neonatal testosterone surge and organizational sexual differentiation of the brain.

Accumulating evidence suggests that embryonic GnRH neurons express Gpr54 and are functionally regulated by kisspeptin in utero (Constantin et al., 2009; Fiorini and Jasoni, 2010; Knoll et al., 2013; Kumar et al., 2014). As such we were interested to explore whether kisspeptin inputs to GnRH neurons may be critical for activating $\mathrm{GnRH}$ neurons in the perinatal period to generate the male testosterone surge. To do this we used a new mouse model with a GnRH neuron-specific deletion of Gpr54 (Kirilov et al., 2013). As is the case for the global Gpr54KO mouse line (Messager et al., 2005), the neuroanatomical distribution of GnRH neurons appears normal in adult GnRH-Gpr54KO mice (Kirilov et al., 2013). Importantly, we show that the neonatal testosterone surge is significantly blunted in male GnRHGpr54KO pups indicating a key role for kisspeptin inputs to male $\mathrm{GnRH}$ neurons in the generation of the neonatal testosterone surge. We note that a recent study failed to find any significant differences in neonatal testosterone concentration in a global Gpr54KO mouse line (Poling and Kauffman, 2012). Again, it is relevant to note that the timing of blood collection is different, as a $0-4 \mathrm{~h}$ interval for the Poling and Kauffman (2012) study is compared with the 1-2 h interval used here. It is likely that the small 1.5-fold sex difference in testosterone levels observed in that study, compared with sixfold reported here, arises from this variability in the window of blood collection.

As the neonatal testosterone surge is substantially attenuated in male GnRH-Gpr54KO pups, it was not surprising to find that organizational brain sexual differentiation is abnormal in these mice. Both the LS vasopressin fibers and preoptic dopamine neurons are female like in GDX $+\mathrm{T}$ male GnRH-Gpr54KO mice. These data are compatible with previous findings demonstrating that the sexual differentiation of TH and Kiss1 mRNA-expressing cells in the RP3V is disrupted in global-Gpr54 knock-out mice (Kauffman et al., 2007). Of note, there is no disruption to the sexually dimorphic characteristics of the female GnRH-Gpr54KO mice. Together, these results indicate that Gpr54 receptors on GnRH neurons in newborn male pups are essential for the establishment of brain sexual differentiation.

The sexually dimorphic activation of perinatal GnRH neurons by kisspeptin would require major sex differences to exist in either Gpr54 expression by GnRH neurons, or their kisspeptin inputs. Similar numbers of male and female GnRH neurons are found to be transcribing Gpr54 at birth (Herbison et al., 2010). This leaves open the possibility that sex differences exist in kisspeptin inputs to $\mathrm{GnRH}$ neurons at birth. To date no consistent sex differences have been found in kisspeptin peptide or mRNA expression in the ARN in the perinatal period (Desroziers et al., 2012b; Walker et al., 2012; Knoll et al., 2013). Importantly, there is now evidence that ARN kisspeptin neurons innervate $\mathrm{GnRH}$ neurons in late gestation in females (Kumar et al., 2014), although it is not known whether this input is sexually dimorphic. An alternative possibility is that a sexually dimorphic kisspeptin input may come from the RP3V as AVPV inputs to GnRH neurons are established before birth (Polston and Simerly, 2006). In reassessing this issue we identified a small population of RP3V kisspeptin neurons that appeared only in perinatal males. It is possible that a similar population may exist in the rat (Desroziers et al., 2012b). Although we presently have no evidence that this perinatal population innervates GnRH neurons, their location 
and temporal profile make it tempting to speculate that they may represent the sexually dimorphic kisspeptin input to GnRH neurons in male pups.

Studies in rodents indicate that there are two distinct increments in testosterone secretion in the second half of embryogenesis. The first occurs from approximately E14-E19 and is independent of gonadotropin secretion (Pointis et al., 1980; Weisz and Ward, 1980; O'Shaughnessy et al., 1998), whereas the second peak occurs shortly after birth and is driven by the GnRH neuron-gonadotropin axis. We provide evidence that the first testosterone rise may in fact be a positive feedforward stimulus driving the male-specific perinatal kisspeptin expression in the RP3V. Administering pregnant dams with testosterone, but not DHT, at E18 generated the same perinatal RP3V kisspeptin population in female P0 pups. These new observations also indicate that there are at least two distinct estrogen-dependent "waves" of kisspeptin expression in the RP3V; a transient perinatal, maledominant population followed by a prepubertal, female-dominant population.

Together the results of the present investigations support the concept that $\mathrm{GnRH}$ neurons are involved in generating the neonatal testosterone surge required for organizational sexual differentiation of the brain. They also highlight a key role for kisspeptin inputs to GnRH neurons in the generation of the neonatal testosterone surge and establishment of brain sex differences. A striking correlation between the transient appearance of a male-specific kisspeptin population in the RP3V and the activation of GnRH neurons has also been observed. Overall, this study extends the role of kisspeptin-Gpr54 signaling at the GnRH neuron beyond that of controlling puberty and adult fertility to the process of sexual differentiation of the brain.

\section{References}

Alves SE, Lopez V, McEwen BS, Weiland NG (1998) Differential colocalization of estrogen receptor beta (ERbeta) with oxytocin and vasopressin in the paraventricular and supraoptic nuclei of the female rat brain: an immunocytochemical study. Proc Natl Acad Sci U S A 95:3281-3286. CrossRef Medline

Arnold AP (2009) The organizational-activational hypothesis as the foundation for a unified theory of sexual differentiation of all mammalian tissues. Horm Behav 55:570-578. CrossRef Medline

Arnold AP, Chen X (2009) What does the "four core genotypes" mouse model tell us about sex differences in the brain and other tissues? Front Neuroendocrinol 30:1-9. CrossRef Medline

Bakker J, Brock O (2010) Early oestrogens in shaping reproductive networks: evidence for a potential organisational role of oestradiol in female brain development. J Neuroendocrinol 22:728-735. CrossRef Medline

Baum MJ, Brand T, Ooms M, Vreeburg JT, Slob AK (1988) Immediate postnatal rise in whole body androgen content in male rats: correlation with increased testicular content and reduced body clearance of testosterone. Biol Reprod 38:980-986. CrossRef Medline

Bu L, Lephart ED (2007) AVPV neurons containing estrogen receptor-beta in adult male rats are influenced by soy isoflavones. BMC Neurosci 8:13. CrossRef Medline

Campbell RE, Herbison AE (2014) Gonadal steroid neuromodulation of developing and mature hypothalamic neuronal networks. Curr Opin Neurobiol 29C:96-102. CrossRef Medline

Clarkson J, Herbison AE (2006) Postnatal development of kisspeptin neurons in mouse hypothalamus; sexual dimorphism and projections to gonadotropin-releasing hormone neurons. Endocrinology 147:58175825. CrossRef Medline

Clarkson J, d'Anglemont de Tassigny X, Moreno AS, Colledge WH, Herbison AE (2008) Kisspeptin-GPR54 signaling is essential for preovulatory gonadotropin-releasing hormone neuron activation and the luteinizing hormone surge. J Neurosci 28:8691-8697. CrossRef Medline

Clarkson J, Boon WC, Simpson ER, Herbison AE (2009a) Postnatal development of an estradiol-kisspeptin positive feedback mechanism implicated in puberty onset. Endocrinology 150:3214-3220. CrossRef Medline
Clarkson J, d'Anglemont de Tassigny X, Colledge WH, Caraty A, Herbison AE (2009b) Distribution of kisspeptin neurons in the adult female mouse brain. J Neuroendocrinol 21:673-682. CrossRef Medline

Clarkson J, Shamas S, Mallinson S, Herbison AE (2012) Gonadal steroid induction of kisspeptin peptide expression in the rostral periventricular area of the third ventricle during postnatal development in the male mouse. J Neuroendocrinol 24:907-915. CrossRef Medline

Constantin S, Caligioni CS, Stojilkovic S, Wray S (2009) Kisspeptin-10 facilitates a plasma membrane-driven calcium oscillator in GnRH-1 neurons. Endocrinology 150:1400-1412. CrossRef Medline

Corbier P, Edwards DA, Roffi J (1992) The neonatal testosterone surge: a comparative study. Arch Int Physiol Biochim Biophys 100:127-131. CrossRef Medline

Corbier P, Kerdelhue B, Picon R, Roffi J (1978) Changes in testicular weight and serum gonadotropin and testosterone levels before, during, and after birth in the perinatal rat. Endocrinology 103:1985-1991. CrossRef Medline

Desroziers E, Mikkelsen JD, Duittoz A, Franceschini I (2012a) Kisspeptinimmunoreactivity changes in a sex- and hypothalamic-region specific manner across rat postnatal development. J Neuroendocrinol 24:11541165. CrossRef Medline

Desroziers E, Droguerre M, Bentsen AH, Robert V, Mikkelsen JD, Caraty A, Tillet Y, Duittoz A, Franceschini I (2012b) Embryonic development of kisspeptin neurones in rat. J Neuroendocrinol 24:1284-1295. CrossRef Medline

De Vries GJ, Panzica GC (2006) Sexual differentiation of central vasopressin and vasotocin systems in vertebrates: different mechanisms, similar endpoints. Neuroscience 138:947-955. CrossRef Medline

de Zegher F, Devlieger H, Veldhuis JD (1992) Pulsatile and sexually dimorphic secretion of luteinizing hormone in the human infant on the day of birth. Pediatr Res 32:605-607. CrossRef Medline

Fiorini Z, Jasoni CL (2010) A novel developmental role for kisspeptin in the growth of gonadotrophin-releasing hormone neurites to the median eminence in the mouse. J Neuroendocrinol 22:1113-1125. CrossRef Medline

Forger NG, de Vries GJ (2010) Cell death and sexual differentiation of behavior: worms, flies, and mammals. Curr Opin Neurobiol 20:776-783. CrossRef Medline

Gill JC, Wang O, Kakar S, Martinelli E, Carroll RS, Kaiser UB (2010) Reproductive hormone-dependent and -independent contributions to developmental changes in kisspeptin in GnRH-deficient hypogonadal mice. PLoS One 5:e11911. CrossRef Medline

Goldman BD, Mahesh VB (1970) Induction of infertility in male rats by treatment with gonadotropin antiserum during neonatal life. Biol Reprod 2:444-451. CrossRef Medline

Goldman BD, Quadagno DM, Shryne J, Gorski RA (1972) Modification of phallus development and sexual behavior in rats treated with gonadotropin antiserum neonatally. Endocrinology 90:1025-1031. CrossRef Medline

Herbison AE (2008) Estrogen positive feedback to gonadotropin-releasing hormone $(\mathrm{GnRH})$ neurons in the rodent: the case for the rostral periventricular area of the third ventricle (RP3V). Brain Res Rev 57:277-287. CrossRef Medline

Herbison AE, de Tassigny Xd, Doran J, Colledge WH (2010) Distribution and postnatal development of Gpr54 gene expression in mouse brain and gonadotropin-releasing hormone neurons. Endocrinology 151:312-321. CrossRef Medline

Hoffman GE, Lee WS, Attardi B, Yann V, Fitzsimmons MD (1990) Luteinizing hormone-releasing hormone neurons express c-fos antigen after steroid activation. Endocrinology 126:1736-1741. CrossRef Medline

Hoffman GE, Smith MS, Verbalis JG (1993) c-Fos and related immediate early gene products as markers of activity in neuroendocrine systems. Front Neuroendocrinol 14:173-213. CrossRef Medline

Kauffman AS, Park JH, McPhie-Lalmansingh AA, Gottsch ML, Bodo C, Hohmann JG, Pavlova MN, Rohde AD, Clifton DK, Steiner RA, Rissman EF (2007) The kisspeptin receptor GPR54 is required for sexual differentiation of the brain and behavior. J Neurosci 27:8826-8835. CrossRef Medline

Kimura K (2011) Role of cell death in the formation of sexual dimorphism in the Drosophila central nervous system. Dev Growth Differ 53:236-244. CrossRef Medline

Kirilov M, Clarkson J, Liu X, Roa J, Campos P, Porteous R, Schütz G, Herbi- 
son AE (2013) Dependence of fertility on kisspeptin-Gpr54 signaling at the GnRH neuron. Nat Commun 4:2492. CrossRef Medline

Knoll JG, Clay CM, Bouma GJ, Henion TR, Schwarting GA, Millar RP, Tobet SA (2013) Developmental profile and sexually dimorphic expression of kiss1 and kiss1r in the fetal mouse brain. Front Endocrinol 4:140. CrossRef

Kumar D, Freese M, Drexler D, Hermans-Borgmeyer I, Marquardt A, Boehm U (2014) Murine arcuate nucleus kisspeptin neurons communicate with GnRH neurons in utero. J Neurosci 34:3756-3766. CrossRef Medline

Lenz KM, Nugent BM, McCarthy MM (2012) Sexual differentiation of the rodent brain: dogma and beyond. Front Neurosci 6:26. CrossRef Medline

Li C, Chen P, Smith MS (1999) Identification of neuronal input to the arcuate nucleus (ARH) activated during lactation: implications in the activation of neuropeptide Y neurons. Brain Res 824:267-276. CrossRef Medline

Livne I, Silverman AJ, Gibson MJ (1992) Reversal of reproductive deficiency in the hpg male mouse by neonatal androgenization. Biol Reprod 47:561567. CrossRef Medline

Luders E, Toga AW (2010) Sex differences in brain anatomy. Prog Brain Res 186:3-12. CrossRef Medline

McCarthy MM, Arnold AP (2011) Reframing sexual differentiation of the brain. Nat Neurosci 14:677-683. CrossRef Medline

McCarthy MM, Arnold AP, Ball GF, Blaustein JD, De Vries GJ (2012) Sex differences in the brain: the not so inconvenient truth. J Neurosci 32: 2241-2247. CrossRef Medline

McGivern RF, Hermans RH, Handa RJ, Longo LD (1995) Plasma testosterone surge and luteinizing hormone beta (LH-beta) following parturition: lack of association in the male rat. Eur J Endocrinol 133:366-374. CrossRef Medline

Messager S, Chatzidaki EE, Ma D, Hendrick AG, Zahn D, Dixon J, Thresher RR, Malinge I, Lomet D, Carlton MB, Colledge WH, Caraty A, Aparicio SA (2005) Kisspeptin directly stimulates gonadotropin-releasing hormone release via G protein-coupled receptor 54. Proc Natl Acad Sci U S A 102:1761-1766. CrossRef Medline

O'Shaughnessy PJ, Baker P, Sohnius U, Haavisto AM, Charlton HM, Huhtaniemi I (1998) Fetal development of Leydig cell activity in the mouse is independent of pituitary gonadotroph function. Endocrinology 139: 1141-1146. CrossRef Medline

Pang SF, Caggiula AR, Gay VL, Goodman RL, Pang CS (1979) Serum concentrations of testosterone, oestrogens, luteinizing hormone and folliclestimulating hormone in male and female rats during the critical period of neural sexual differentiation. J Endocrinol 80:103-110. CrossRef Medline

Paxinos G, Franklin KBJ (2001) The mouse brain atlas in stereotaxic coordinates, Ed 2. San Diego: Academic.

Plant TM (1985) A study of the role of the postnatal testes in determining the ontogeny of gonadotropin secretion in the male rhesus monkey (Macaca mulatta). Endocrinology 116:1341-1350. CrossRef Medline

Pointis G, Latreille MT, Cedard L (1980) Gonado-pituitary relationships in the fetal mouse at various times during sexual differentiation. J Endocrinol 86:483-488. CrossRef Medline

Poling MC, Kauffman AS (2012) Sexually dimorphic testosterone secretion in prenatal and neonatal mice is independent of kisspeptin-Kiss1r and GnRH signaling. Endocrinology 153:782-793. CrossRef Medline

Polston EK, Simerly RB (2006) Ontogeny of the projections from the anteroventral periventricular nucleus of the hypothalamus in the female rat. J Comp Neurol 495:122-132. CrossRef Medline

Roa J, Navarro VM, Tena-Sempere M (2011) Kisspeptins in reproductive biology: consensus knowledge and recent developments. Biol Reprod 85: 650-660. CrossRef Medline

Semaan SJ, Murray EK, Poling MC, Dhamija S, Forger NG, Kauffman AS (2010) BAX-dependent and BAX-independent regulation of Kiss1 neuron development in mice. Endocrinology 151:5807-5817. CrossRef Medline

Simerly RB (1989) Hormonal control of the development and regulation of tyrosine hydroxylase expression within a sexually dimorphic population of dopaminergic cells in the hypothalamus. Brain Res Mol Brain Res 6:297-310. CrossRef Medline

Simerly RB (2002) Wired for reproduction: organization and development of sexually dimorphic circuits in the mammalian forebrain. Annu Rev Neurosci 25:507-536. CrossRef Medline

Simerly RB, Zee MC, Pendleton JW, Lubahn DB, Korach KS (1997) Estrogen receptor-dependent sexual differentiation of dopaminergic neurons in the preoptic region of the mouse. Proc Natl Acad Sci U S A 94:1407714082. CrossRef Medline

Simonian SX, Herbison AE (2001) Differing, spatially restricted roles of ionotropic glutamate receptors in regulating the migration of GnRH neurons during embryogenesis. J Neurosci 21:934-943. Medline

Walker DM, Kirson D, Perez LF, Gore AC (2012) Molecular profiling of postnatal development of the hypothalamus in female and male rats. Biol Reprod 87:129. CrossRef Medline

Weisz J, Ward IL (1980) Plasma testosterone and progesterone titers of pregnant rats, their male and female fetuses, and neonatal offspring. Endocrinology 106:306-316. CrossRef Medline

Wen S, Ai W, Alim Z, Boehm U (2010) Embryonic gonadotropin-releasing hormone signaling is necessary for maturation of the male reproductive axis. Proc Natl Acad Sci U S A 107:16372-16377. CrossRef Medline

Wu S, Wilson MD, Busby ER, Isaac ER, Sherwood NM (2010) Disruption of the single copy gonadotropin-releasing hormone receptor in mice by gene trap: severe reduction of reproductive organs and functions in developing and adult mice. Endocrinology 151:1142-1152. CrossRef Medline 